\title{
PEMANFAATAN BUKU 'Choukai ga Yowai, Anata e' DALAM MENINGKATKAN KEMAMPUAN CHOUKAI (Penelitian Kuasi Untuk Mahasiswa Tingkat III Tahun Ajar 2015 / 2016 Departemen Pendidikan Bahasa Jepang FPBS UPI)
}

\author{
PANGESTU RAMADHAN, Neneng Sutjiati'), Renariah ${ }^{2)}$ \\ Departemen Pendidikan Bahasa Jepang, Fakultas Pendidikan Bahasa dan Sastra, Universitas \\ Pendidikan Indonesia \\ padasuka103@gmail.com
}

\begin{abstract}
Abstrak
Penggunaan media dalam pembelajaran, khususnya dalam pembelajaran bahasa asing dinilai sangat penting. Dalam bahasa Jepang terutama, dalam menangkap cara berbicara penutur asli dan untuk membiasakan diri. Dalam penelitian ini penulis mencoba untuk menggunakan media 'Choukai ga Yowai, Anata e' sebagai pembantu pembelajar untuk meningkatkan kemampuan menyimak atau choukai masing masing pembelajar. Tujuan dari penelitian ini adalah untuk mengetahui pembelajaran menyimak dengan menggunakan bantuan media buku 'Choukai ga Yowai, Anata e', perbedaan antara hasil pre test dan post test setelah pembelajaran, untuk mengetahui tanggapan dari masing - masing objek setelah diadakannya penelitan, mengolah data untuk mengetahui hasil dari penelitian dalam pembelajaran dengan menggunakan media pembelajaran 'Choukai ga Yowai, Anata e'. Metode yang digunakan dalam penelitian ini yaitu metode penelitian kuasi, dengan objek yaitu mahasiswa tingkat III departemen pendidikan bahasa Jepang angkatan 2015 / 2016 sebanyak 20 orang. Instrumen yang digunakan adalah tes dan angket. Dari hasil penelitian yang didapatkan bahwa $\mathrm{t}$ hitung adalah 4,41>t tabel 2,10 untuk $5 \%$ dan $\mathrm{t}$ hitung adalah 4,41 > t tabel 2,88 untuk 1\%. $\mathrm{t}$ hitung $>\mathrm{t}$ tabel yang berarti $\mathrm{H}_{\mathrm{a}}$ diterima. Hal ini membuktikan bahwa terdapat perbedaan yang signifikan perolehan kemampuan choukai setelah menggunakan media buku 'Choukai ga Yowai, Anata e'. Kemudian berdasarkan hasil angket yang didapatkan pula dapat diketahui bahwa objek merekomendasikan penggunaan media buku ini.
\end{abstract}

Kata kunci : Choukai, Media, 'Choukai ga Yowai, Anata e'

\footnotetext{
${ }^{1}$ Penulis Penanggung Jawab 1

${ }^{2}$ Penulis Penanggung Jawab 2
} 
USES OF BOOK MEDIA 'CHOUKA/ GA YOWAI ANATA E TO IMPROVE CHOUKA/SKILLS

\title{
(Quasi Experimental Method for Third Grade Students of Japanese Language Education Department FPBS UPI, Year Study : 2015 / 2016)
}

\author{
PANGESTU RAMADHAN, Neneng Sutjiati'), Renariah' ${ }^{2)}$ \\ Departemen Pendidikan Bahasa Jepang, Fakultas Pendidikan Bahasa dan Sastra, Universitas \\ Pendidikan Indonesia \\ padasuka103@gmail.com
}

\begin{abstract}
The importance of media uses in educational fields are very significance. Especially, in Japanese language learning, the main objective of media uses is for understand the way of native speaker how to conversation with their languange and to improve our skills. In this time, writer has conducted an experiment with a media, its called 'Choukai ga Yowai, Anata e' to support and improve the listening skill of learners. The objective of experiments are to detect the differences between before (pretest) and after (postest) of the uses, to explain the feedbacks from the experiment objects, processing the data to understand the result after used the media at experimental class. Method that used on this experiment are quasi method experiment. With the objects are 20 students of third grade of Japanese Language Department, year study : 2015 - 2016. The used instruments are test form and questionnaire. From the result of experiments, are known that calculated $\mathrm{t}$ is $4,41>\mathrm{t}$ table 2,10 for $5 \%$ and 4,41>t table 2,88 for $1 \%$. Calculated $t>t$ table, the result, $H_{a}$ are accepted. Based on this result, its proved that significance difference of results after the objects used media of 'Choukai ga Yowai, Anata e'. Also, based of questionnaire results that the objects recommended the uses of this media at listening class.
\end{abstract}

Keyword: Choukai, Media, 'Choukai ga Yowai, Anata e' 
Ramadhan, Sutjiati, Renariah, Pemanfaatan Buku 'Choukai ga Yowai Anata e'

\title{
日本語の学習の聴解力を高めるため「聴解が弱い、あなたへ」という 媒体の使用 \\ (インドネシア教育大学の日本語教育部の $2015-2016$ 年生に対する 準研究)
}

パンゲストゥ・ラマダン、ネネング・スチアティ ${ }^{1)}$ 、レナリアー2)

\section{padasuka103@gmail.com}

\begin{abstract}
要旨
言語の学習には媒体の使用が必要だと考えられる。特に日本語の授業では 慣れるためであり、ネーティブスピーカーの言い方が分かるためである。本研究では 「聴解が弱い、あなたへ」という媒体での一助になって学習者の聴解力を高めること ができる期待される。本研究の目的は「聴解が弱い、あなたへ」という媒体での聴解 の授業の影響を知るためであり、前半テストの結果と後半テストの結果は差があるか のを知るためであって対象からの反応を知るためであって行われた「聴解が弱い、あ なたへ」での授業の結果の資料を分析して知るためである。本研究の方法は準研究で ある。対象はインドネシア教育大学の日本語教育部の 2015/2016 年回の 3 年生の 20 名 である。用器はテストとアンケットである。入手したデータには t 数点は $4,41>5 \%$ の有意義の $\mathrm{t}$ 表には 2,10 で、 $\mathrm{t}$ 数点 $>1 \%$ の有意義の $\mathrm{t}$ 表には 2,88 である。というわ けで、 $\mathrm{H}_{1}$ の解棌は受け取れる。それで、「聴解が弱い、あなたへ」という媒体での聴 解の授業の結果は有意差がある。そして、アンケットのデータの結果により、対象が この媒体をすすめると解答される。
\end{abstract}

キーワード : 聴解、媒体、「聴解が弱い、あなたへ」 


\section{PENDAHULUAN}

Ketika mempelajari bahasa asing yang digunakan sebagai alat komunikasi, sangatlah penting untuk mengontrol empat aspek dasar berbahasa. Dalam mempelajari bahasa Jepang pun merupakan hal yang sama. Empat aspek tersebut antara lain menyimak, membaca, berbicara, dan menulis. Dengan empat aspek tersebut yang saling berhubungan dan mendukung satu sama lainnya, pembelajar supaya dapat mengontrol pemahaman dan arti, juga menambah masing - masing kosakata dan pengetahuan kebahasaan. Ando (2011, hlm.2) menyatakan bahwa, "baik dalam mendengar, berbicara, membaca, menulis, dan dalam bidang apapun juga, apabila semakin banyak kosakata yang dipahami, akan menjadi sebuah kemampuan".

Multimedia bukanlah hal yang langka, dan sangat lazim juga menjadi favorit untuk digunakan sebagai penolong dalam meningkatkan kemampuan belajar. Kemudian karena hal itu bagi pembelajar merupakan salah satu alternatif dan multimedia dapat dipilih sesuai dengan minat dan kemampuan kita sendiri. Juga media untuk meningkatkan kemampuan menyimak atau choukai beragam sekali jenisnya. Akan tetapi harus diperhatikan mengenai cara penyampaian dan isi dari media tersebut untuk mendapatkan manfaat bagi pembelajar.

Jenis media yang sering dipergunakan dalam pembelajaran menyimak adalah media audio. Manfaat menggunakan media tersebut antara lain dapat mendengar isi dari media secara berulang - ulang dimanapun kapanpun dan dapat memperhatikan secara mendalam cara pengucapan dan cara berbicara dari para penutur asli, yang akan menjadikannya sebuah efektifitas dalam pembelajaran. Juga karena perkembangan teknologi, menjadi sangat lazim mempergunakan media audio dalam bentuk kecil seperti CD dan DVD. Hal tersebut, menjadi salah satu hal yang penting.

Dalam penelitian, media yang akan dipergunakan adalah media buku 'Choukai ga Yowai, Anata e'. Dipikirkan pula bahwa sangat cocok apabila penelitian ini bertujuan untuk meningkatkan kemampuan menyimak baik bagi pembelajar pemula ataupun pembelajar yang mengalami kesulitan dengan memperhatikan isi dan audio yang terdapat didalam buku ini. Kemudian dalam penelitian ini pula bertujuan untuk menemukan titik lemah diantara objek penelitian (pembelajar) sekaligus untuk meningkatkan kemampuan menyimaknya.

\section{METODE}

Metode yang digunakan dalam penelitian ini yaitu metode penelitian quasi atau quasi experimental method. Desain penelitian ini menggunakan satu grup dan didalamnya dengan mengadakan pretest dan posttest. Menurut Sugiyono (2012, hlm.77), Penelitian quasi merupakan penelitian yang dilakukan apabila penelitian murni tidak bisa dilakukan. Di dalam desain penelitian ini, dilakukan dengan satu grup tanpa menggunakan dua buah grup seperti biasanya.Dengan populasi berasal dari mahasiswa Departemen Pendidikan Bahasa Jepang, FPBS - UPI tingkat III tahun ajar 2015 / 2016 dan sampel sebanyak 20 orang. Langkah - langkah penelitian akan dijelaskan dibawah ini :

a. Langkah - langkah pengambilan data : 
1. Menentukan soal - soal dalam pretest, treatment, dan posttest

2. Menyusun soal - soal dalam pre test, treatment, dan post test.

3. Mengadakan pre test kepada objek penelitian.

4. Mengumpulkan data dari pre test.

5. Mengadakan treatment atau kelas kontrol.

6. Mengadakan post test.

7. Mengumpulkan data dari post test.

8. Membandingkan data dari pre test, dan post test.

9. Mengolah data yang dikumpulkan.

10. Menyimpulkan data yang telah didapat.

b. Langkah - langkah pengolahan data

Setelah data penelitian didapatkan, hasil dari pretest dan posttest kemudian diolah untuk mengetahui hasil dari penelitian. Dalam bagian ini mempergunakan rumus pengolahan data dan membandingkan hasil antara pretest dan posttest. Setelahnya data hasil dari angket mengenai penelitian pun diolah.

a) Untuk mengetahui rata - rata dari beda hasil pretest dan posttest

$\overline{\mathrm{D}}=\frac{\sum \mathrm{D}}{N}$

Keterangan

$\sum \mathrm{D} \quad$ : Jumlah keseluruhan nilai beda antara pretest dan posttest

$N \quad$ : Jumlah objek penelitian

b) Menghitung $\mathrm{T}$

$t=\frac{\overline{\mathrm{D}}}{\sqrt{\frac{\sum \mathrm{D}^{2}-\frac{\left(\sum \mathrm{D}\right)^{2}}{N}}{N(N-1)}}}$

Keterangan :

$t \quad$ : harga $\mathrm{t}$ untuk sampel berkorelasi.

$\overline{\mathrm{D}} \quad$ : (difference), perbedaan antara skor tes awal dengan skor tes akhir untuk setiap individu.

$\Sigma \mathrm{D} \quad$ : rerata dari nilai perbedaan (rerata dari D).

$\Sigma \mathrm{D}^{2} \quad$ : kuadrat dari D.

$N \quad$ : banyaknya subjek penelitian.

(dari Arikunto, 1990, hlm. 508) 
c) Pengujian nilai $t$

Dalam pengujian nilai $t$ tersebut setelah didapat, maka akan ditentukan hipotesis tersebut dengan mengujinya menggunakan nilai tabel kebebasan $t$ atau t tabel. Hasil yang akan didapat setelah pengujian tersebut adalah sebagai berikut :

a. $\mathrm{t}$ hitung lebih besar daripada nilai $\mathrm{t}$ tabel maka $\mathrm{H}_{1}$ diterima dan $\mathrm{H}_{0}$ ditolak

b. thitung lebih kecil daripada nilai t tabel maka $\mathrm{H}_{0}$ diterima dan $\mathrm{H}_{1}$ ditolak

Sedangkan untuk menentukan jumlah $\mathrm{db}$ yang sesuai dengan $\mathrm{t}$ tabel, sebelumnya digunakan rumus sebagai berikut : $\mathrm{Db}=(\mathrm{n}-1)$, dengan menggunakan nilai t tabel dalam daya kebebasan sebanyak $5 \%$ dan $1 \%$.

d) Mengolah data angket

Setelah mengadakan penelitian, peneliti membagikan angket untuk mengetahui informasi dan tanggapan mengenai penelitian berdasarkan objek penelitian. Rumus untuk mengolah data angket, menggunakan rumus dibawah ini

$$
P=\frac{f}{N} \mathrm{X} 100 \%
$$

Keterangan :

$P=$ Presentase angket

$f=$ Jumlah pilihan jawaban yang dipilih

$N=$ Jumlah koresponden

e) Hipotesis mengenai jumlah data angket

\begin{tabular}{|c|c|}
\hline Interval Presentase & Interprestasi \\
\hline $0 \%$ & Tidak seorang pun \\
\hline $1 \%-5 \%$ & Hampir tidak ada \\
\hline $6 \%-25 \%$ & Sebagian kecil \\
\hline $26 \%-49 \%$ & Hampir Setengahnya \\
\hline $50 \%$ & Setengahnya \\
\hline $51 \%-75 \%$ & Lebih dari setengahnya \\
\hline $76 \%-95 \%$ & Sebagian besar \\
\hline $96 \%-99 \%$ & Hampir seluruhnya \\
\hline $100 \%$ & Seluruhnya \\
\hline
\end{tabular}

c. Instrumen Penelitian

Penelitian ini menggunakan tes dan angket.

1) Tes

Tes yang akan diadakan dalam penelitian ini dibagi menjadi dua tes, antara lain pada saat tes awal (pretest), dan tes akhir (posttest). Pada tes awal (pretest), dilakukan untuk melihat hasil dari objek penelitian sebelum diadakannya treatment dan tes akhir (posttest) dilaksanakan setelah 
diadakannya treatment, untuk mengetahui sejauh mana terlihat peningkatan setelah menggunakan buku ini.

2) Angket

Teknik angket menurut Faisal (dalam Sutedi, 2009, hlm. 164), "dilakukan dengan cara pengumpulan datanya melalui daftar pertanyaan tertulis yang disusun dan disebarkan untuk mendapatkan informasi atau keterangan dari responden." Angket akan dibagikan kepada objek penelitian untuk mengetahui sejauh mana tanggapan para pembelajar sendiri dalam penelitian ini

\section{HASIL DAN PEMBAHASAN}

Terhadap objek penelitian, telah diberikan pembelajaran berdasarkan buku 'Choukai ga Yowai, Anata e'. Dalam tiga kali treatment diberikan pula cara - cara untuk meningkatkan kemampuan menyimak. Dalam kegiatan ini pun diberikan beberapa latihan soal.

Dibawah ini merupakan hasil dari penelitian dari pembelajaran menggunakan buku 'Choukai ga Yowai, Anata e' :

Tabel Nilai Hasil Pretest dan Posttest

\begin{tabular}{|c|c|c|c|c|}
\hline $\begin{array}{l}\text { Sampel } \\
\text { No. }\end{array}$ & Nilai tes awal & Nilai tes akhir & Nilai beda & Nilai beda kuadrat $\left(\mathrm{D}^{2}\right)$ \\
\hline 1 & 6,4 & 8,5 & 2,1 & 4,41 \\
\hline 2 & 4,8 & 7,6 & 2,8 & 7,84 \\
\hline 3 & 4,2 & 5,2 & 1,0 & 1,0 \\
\hline 5 & 4,2 & 6,4 & 2,2 & 4,84 \\
\hline 6 & 6,1 & 7,6 & 1,5 & 2,25 \\
\hline 7 & 3,9 & 7,9 & 3,9 & 15,21 \\
\hline 8 & 7,6 & 8,5 & 0,9 & 0,81 \\
\hline 9 & 6,1 & 7,6 & 1,5 & 2,25 \\
\hline 10 & 5,2 & 6,4 & 1,2 & 0,44 \\
\hline 11 & 9,4 & 9,7 & 0,3 & 0,36 \\
\hline 12 & 6,1 & 6,7 & 0,6 & 0,81 \\
\hline 13 & 7,6 & 8,5 & 0,9 & 0,09 \\
\hline 14 & 3,6 & 3,9 & 0,3 & 7,84 \\
\hline 15 & 5,1 & 7,9 & 2,8 & 24,01 \\
\hline 16 & 3,0 & 7,9 & 4,9 & 1,2 \\
\hline 17 & 3,0 & 4,2 & & \\
\hline
\end{tabular}




\begin{tabular}{|c|c|c|c|c|}
\hline 18 & 4,8 & 7,6 & 2,8 & 7,84 \\
\hline 19 & 6,7 & 8,5 & 1,8 & 3,24 \\
\hline 20 & 8,2 & 6,7 & $-2,5$ & 6,25 \\
\hline$\Sigma$ & 106 & 137,3 & 30,2 & 92,02 \\
\hline
\end{tabular}

Berdasarkan data diatas, data diolah dengan menggunakan langkah langkah berikut :

1. Mencari rerata dari nilai beda antara pretest dengan posttest (D) dengan rumus :

$$
\begin{aligned}
& \overline{\mathrm{D}}=\frac{\Sigma \mathrm{D}}{N} \\
& \overline{\mathrm{D}}=\frac{30,2}{19} \\
& \overline{\mathrm{D}}=1,589
\end{aligned}
$$

2. Mencari t-hitung dan memberikan interpretasi terhadap nilai $\mathrm{t}-$ hitung

$$
\begin{aligned}
& t=\frac{\overline{\mathrm{D}}}{\sqrt{\frac{\Sigma \mathrm{D}^{2}-\frac{(\Sigma \mathrm{D})^{2}}{N}}{N(N-1)}}} \\
& t=\frac{1,589}{\sqrt{\frac{92,02-\frac{(30,2)^{2}}{19}}{19(19-1)}}} \\
& t=\frac{1,589}{\sqrt{\frac{92,02-\frac{912,04}{19}}{19(18)}}} \\
& t=\frac{1,589}{\sqrt{\frac{44,02}{342}}} \\
& t=\frac{1,589}{\sqrt{0,129}} \\
& t=4,41
\end{aligned}
$$


3. Signifikasi dengan derajat kebebasan $(\mathrm{df} / \mathrm{db})$

df atau db $=\mathrm{N}-1$

$$
\begin{aligned}
& =19-1 \\
& =18
\end{aligned}
$$

Pada taraf signifikasi $5 \%, \mathrm{t}-$ tabel $=2,10$

Pada taraf signifikasi $1 \%, \mathrm{t}-$ tabel $=2,88$

Dengan demikian, $\mathrm{t}$ hitung adalah $4,41>\mathrm{t}$ tabel 2,10 untuk $5 \%$ dan $\mathrm{t}$ hitung adalah 4,41>t tabel 2,88 untuk $1 \%$. $\mathrm{t}$ hitung $>\mathrm{t}$ tabel yang berarti $\mathrm{H}_{\mathrm{a}}$ diterima. Hal ini membuktikan bahwa terdapat perbedaan yang signifikan perolehan kemampuan choukai setelah menggunakan media buku 'Choukai ga Yowai, Anata e'.

4. Tanggapan mengenai penelitian berdasarkan angket

Setelah mengadakan posttest, dibagikan angket kepada objek penelitian. Tanggapan dari 14 orang diantara 20 orang beranggapan bahwa penggunaan media ini menarik. Kualitas yang berada didalam media buku ini pun baik dan terdengar jelas. Kemudian materi ajar dalam buku ini dapat dengan mudah dipelajari dan dalam angket objek penelitian menjawab bahwa merekomendasikan media buku ini. Objek penelitian menjawab bahwa penelitian ini disampaikan dengan baik.

\section{KESIMPULAN}

Hasil yang didapatkan sesudah diadakannya penelitian adalah sebagai berikut :

1. Nilai rata - rata sebelum diadakannya treatment yaitu 5,5 dan nilai rata - rata setelah diadakannya treatment yaitu 7,2.

2. Peningkatan nilai hasil penelitian setelah menggunakan media buku ini berdasarkan hipotesis yang tersedia, terdapat peningkatan yang signifikan. Yaitu $\mathrm{t}$ hitung adalah 4,41>t tabel 1,73 untuk $5 \%$ dan $\mathrm{t}$ hitung adalah $4,41>\mathrm{t}$ tabel 2,54 untuk $1 \%$. $\mathrm{t}$ hitung $>\mathrm{t}$ tabel yang berarti $\mathrm{H}_{\mathrm{a}}$ diterima.

3. Berdasarkan hasil angket yang telah didapatkan tanggapan pembelajar dalam menggunakan media pembelajaran ini adalah bahwa penggunaan media buku 'Choukai ga Yowai, Anata e' ini menarik dan dapat menjadi rekomendasi sebagai media untuk membantu pembelajaran, khususnya dalam menyimak.

\section{DAFTAR PUSTAKA}

Arikunto, Suharsimi. (1990) Manajemen Penelitian. Jakarta : Rineka Cipta

Brooks, Nelson. (1964) Language and Language Learning. New York : Harcourt, Brace, and World

Nurjamal, Daeng; Sumirat, Warta; Darwis Riadi. (2011) Terampil

Berbahasa:Menyusun Karya Tulis Akademik, Memandu Acara (MC-

Moderator), dan Menulis Surat. Bandung : Alfabeta 
Sadiman, Arief S., dkk. (2009) Media Pendidikan : Pengertian, Pengembangan, dan Pemanfaatannya. Jakarta : Bhineka Cipta.

Sutedi, Dedi. (2009) Penelitian Pendidikan Bahasa Jepang.Bandung : Humaniora Press

Tarigan, Henry Guntur. (1983) Menyimak: Sebagai Suatu Keterampilan Berbahasa. Bandung : Angkasa

安藤栄里子、惠谷容子、飯嶋美知子 (2010) 耳から覚える日本語能力試験文 法トレーニング N3. Tokyo : ALC Press Inc. 


\section{日本語の学習の聴解力を高めるため「聴解が弱い、あなたへ」という 媒体の使用 \\ （インドネシア教育大学の日本語教育部の $2015-2016$ 年生に対する 準研究)}

\section{1. はじめに}

コミュニケーションのツールとしての外国語を学習する場合、基本的な言語の四 つの技能について把握するのが重要である。日本語を学習するのもそいうことと同一 なものである。そのこととは聞くことと、読むこと、話すこと、書くことである。つ ながっていて支配をもつ四つの要素は言語知識と個々な単語を増加して理解と意味を 把握するためである。安藤（2010,p.2）は「聞く、話す、読む、書く、どの分野でも、 知ってる言葉の数が多ければ、多いほど、それ 力となります。」と述べている。

その間に一つの基本にある日本語教育の部分は聴解である。リスニングによって 日本語を覚えるのには一つの利点がある。学習者に言語自体の知識を把握させ、実社

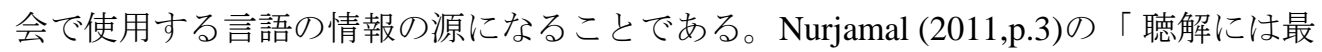
初に我々が習うことを理解する必要性があり、情報を集めるのに大変有用である」と いう理論によると、聴解は外国語の習得を容易にするである。特に日本語においても。 近代に放し、使用している技術で難しくて問題になる聴解の授業はあまりなく、ラジ オでもデジタルオーディオでも動画でも多様な媒体で授業が行える可能になる。

Sadiman(2009,p.6) によるとメディアとは「Medium」の複数形で諼渡かつ媒質とい う意味があり、また情報の発信側から受信側への媒質および送り手という意味がある

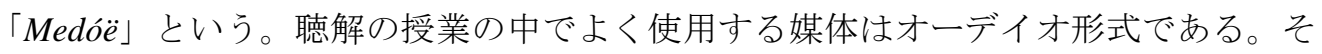
の媒体では学習者に適当な情報や発音、正解に言い方を伝うことができる。オーディ オでは当たりに伝えた音声が聞かせたのでよい媒体になる。Nurjamal (2011,p.3)

聴解と会話は直接に表裏のコミュニケーションの種類にして「Face to Face communication」という（Brooks, 1964, p.134）。聴解は会話と共に社会でよく使用し ている言語技能ので、気付くのがないか授業の中で放出する受け入れる教材はない。 よい聴解力がある学習者はコミュニケーションの道具として学習した外語が展開でき る。Tariganによると、新入学生について研究は聴解の授業を受け入れた学生が最初 に授業が行う前に $27 \%$ の人は次の授業の内容を把握することができたのに、50\%のよ い聴解力をもっている人は授業の後に、学力を進歩することができる。(Tarigan, 1983, p.10) 
マルチメディアは珍しくなく、学力を高めるような一助としたもので気に入れて はやっている。それで学習者には択一になり、自分の興味と能力に合って選択するこ とができる。聴解力を高まるための媒体も多様な種類がある。ただし学習に利益が得 られるのはもっとも内容と伝い方を観察しなければならない。

聴解の授業の中でよく使用寸る媒体はオーディオの種類である。その使用の利益 はどこでも何でも聞き直すことができてナーティブスピーカーからの言い方と発音が はっきりと注意することができ、効果的に授業が行える。開発している技術のでデー タをもつ小型の CD と DVD の使用がはやっているようになる。さらに必要な一要素 だと思われる。

本研究での実験の媒体は「聴解が弱い、あなたへ」という媒体である。内容と付 けるオーディオが難易がある学生にも入門学生にも聴解力を高める目的があるのは合 えると思われる。そして、他の目的は対象（学習者）の中に弱点を見つかることおよ び聴解力を高めるためである。

\section{2. 研究の方法}

本研究の方法は準実験研究（Quasi Experimental Research Design）である。デザイ ンは一つのグループに事前テストと事後テストをかかる。Sugiyono (2012,p.77)により、準 実験研究は難解に行えない実験研究からの開発である。そのデザインには 2 群を必要とし ずに、一つグループと研究することができる。

サンプルはインドネシア教育大学の日本語教育部の 2013 年学生の 20 名である。 研究の対象として三つクラスから 20 名をランダムに選択した。本研究の手法は下記に説 明する。

a. 研究のデータを収集する手法

1. 事前テスト、トリートメント、事後テストの問題集を作成する。

2. 実験の最初では対象に事前テストをあげる。

3. 事前テストの結果のデータを収集する。

4. 対象にテストの結果を見せて後には択一教具として「聴解が弱い、あなたへ」で 3 回の 処理にする。

5. 事後テストの結果のデータを収集する。

6. 対象に事後テストをあげて事前テストと事後テストの結果を比較する。

7. フィードバックと感想を知るためのアンケットを対象に配る。

8. 事前テストと事後テストの結果を比較し、分析をする。

9. 仮説でデータを説明する。

10.まとめをたてる。 
Ramadhan, Sutjiati, Renariah, Pemanfaatan Buku 'Choukai ga Yowai Anata e'

b. データを分析する手法

研究のデータを収集した後、結果を知るように事前テストと事後テストの成績を分析 する。この部分では統計の方式を使用し、事前テストと事後テストを比較する。最後、 研究についてアンケットの結果を分析する。

a）事前テストと事後テストの差の平均を計算する。

$$
\overline{\mathrm{D}}=\frac{\sum \mathrm{D}}{N}
$$

説明

$\sum \mathrm{D} \quad$ : 事前テストと事後テストの点数の差の合計

$N$ : 研究対象の人数

b) $\mathrm{t}$ 点数を計算する。

$$
t=\frac{\overline{\mathrm{D}}}{\sqrt{\frac{\sum \mathrm{D}^{2}-\frac{\left(\sum \mathrm{D}\right)^{2}}{N}}{N(N-1)}}}
$$

説明

$\overline{\mathrm{D}} \quad$ ： (difference)、事前テストと事後テストの点数の差

$\sum \mathrm{D}: \mathrm{D}$ 合計の平均

$\Sigma \mathrm{D}^{2} \quad \mathrm{D}$ の二次方程式

$N$ : 研究対象の人数

(Arikunto, 1990, p. 508)

c) $\mathrm{t}$ 点数のバリュー解釈する。

この二つの仮説は $\mathrm{t}$ 得点と $\mathrm{t}$ 表のバリューを比較する。あたはめる仮説実験は次のように 説明する。

1. $\mathrm{t}$ 得点 $>\mathrm{t}$ 表の場合は $\mathrm{H}_{1}$ は受け取れるが $\mathrm{H}_{0}$ は断れる。

2 . $\mathrm{t}$ 得点 $<\mathrm{t}$ 表の場合は $\mathrm{H}_{0}$ は受け取れるが $\mathrm{H}_{1}$ は断れる。 
$\mathrm{t}$ 表のバリューを決定する方法はその前に $\mathrm{df} / \mathrm{db}=(\mathrm{n}-1)$ の方式で自由度を決定。 $\mathrm{Df} / \mathrm{db}$ を決めたら、5\%と $1 \%$ の有意義に分かる。

d）アンケットのデータを分析の方法。

研究実験を行われたあと、対象からの研究についての情報と印象を手引くためアンケッ トを配った。アンケットを分析するのは下記の方式で使用する。

$$
P=\frac{f}{N} \mathrm{X} 100 \%
$$

説明

$P$ 解答の頻度率

$f=$ 頻度

$N=$ 被験者の人数

e）アンケットの結果を次のデータと解釈する。

\begin{tabular}{|c|c|}
\hline $0,00 \%$ & いない \\
\hline $01,00 \%-05,00 \%$ & ほとんどいない \\
\hline $06,00 \%-25,00 \%$ & 一部いる \\
\hline $26,00 \%-49,00 \%$ & 半分以下 \\
\hline $50,00 \%$ & 半分 \\
\hline $51,00 \%-75,00 \%$ & 半分以上 \\
\hline $76,00 \%-95,00 \%$ & かなり多い \\
\hline $96,00 \%-99,00 \%$ & ほとんど全部 \\
\hline $100 \%$ & 全部 \\
\hline
\end{tabular}

c. 研究の用器

本研究の用器はテストとアンケットである。

1）テスト

研究の中にあるテストは二回に行われる。それは事前テストと事後テストである。 事前テストはトリートメントの前に対象からの結果を知るためであり、事後テス 卜は「聴解が弱い、あなたへ」という媒体でのトリートメントの後、テストが行 われて差異の結果を見、かけられた。

2）アンケット

アンケットとは Faisal により、整頓された質問でデータを収集する方法であり、 情報と解説を受け入れるため被験者に配っている(Sutedi, 2009, p.164)。このアンケ ットは研究実験について被験者からの反応と印象を知るためである。 
Ramadhan, Sutjiati, Renariah, Pemanfaatan Buku 'Choukai ga Yowai Anata e'

3. 研究の結果

対象に「聴解が弱い、あなたへ」の内容で学習してかけた。三回にトリートメン トが行われ、そして聴解力を高めるための方法を伝えてあげる。この内容でもドリルをす る。

「聴解が弱い、あなたへ」での授業して前後の結果を総計的な計算は説明する：

\begin{tabular}{|c|c|c|c|c|}
\hline $\begin{array}{l}\text { サンプ } \\
\text { ルの号 }\end{array}$ & $\begin{array}{c}\text { 事前テストの } \\
\text { 数点 }\end{array}$ & $\begin{array}{c}\text { 事後テストの } \\
\text { 数点 }\end{array}$ & 数点の差 & 二次方程式 $\left(\mathrm{D}^{2}\right)$ \\
\hline 1 & 6,4 & 8,5 & 2,1 & 4,41 \\
\hline 2 & 4,8 & 7,6 & 2,8 & 7,84 \\
\hline 3 & 4,2 & 5,2 & 1,0 & 1,0 \\
\hline 5 & 4,2 & 6,4 & 2,2 & 4,84 \\
\hline 6 & 6,1 & 7,6 & 1,5 & 2,25 \\
\hline 7 & 3,9 & 7,9 & 3,9 & 15,21 \\
\hline 8 & 7,6 & 8,5 & 0,9 & 0,81 \\
\hline 9 & 6,1 & 7,6 & 1,5 & 2,25 \\
\hline 10 & 5,2 & 6,4 & 1,2 & 1,44 \\
\hline 11 & 9,4 & 9,7 & 0,3 & 0,09 \\
\hline 12 & 6,1 & 6,7 & 0,6 & 0,36 \\
\hline 13 & 7,6 & 8,5 & 0,9 & 0.81 \\
\hline 14 & 3,6 & 3,9 & 0,3 & 0.09 \\
\hline 15 & 5,1 & 7,9 & 2,8 & 7,84 \\
\hline 16 & 3,0 & 7,9 & 4,9 & 24,01 \\
\hline 17 & 3,0 & 4,2 & 1,2 & 1,44 \\
\hline 18 & 4,8 & 7,6 & 2,8 & 7,84 \\
\hline 19 & 6,7 & 8,5 & 1,8 & 3,24 \\
\hline 20 & 8,2 & 6,7 & $-2,5$ & 6,25 \\
\hline$\Sigma$ & 106 & 137,3 & 30,2 & 92,02 \\
\hline
\end{tabular}

a) 事前テストと事後テストの差の平均を計算する。

$$
\begin{aligned}
& \overline{\mathrm{D}}=\frac{\sum \mathrm{D}}{N} \\
& \overline{\mathrm{D}}=\frac{30,2}{19}
\end{aligned}
$$


$\overline{\mathrm{D}}=1,589$

b) $\mathrm{t}$ 点数を計算する。

$$
\begin{aligned}
& t=\frac{\overline{\mathrm{D}}}{\sqrt{\frac{\Sigma \mathrm{D}^{2}-\frac{(\Sigma \mathrm{D})^{2}}{N}}{N(N-1)}}} \\
& t=\frac{1,589}{\sqrt{\frac{92,02-\frac{(30,2)^{2}}{19}}{19(19-1)}}} \\
& t=\frac{1,589}{\sqrt{\frac{92,02-\frac{912,04}{19}}{19(18)}}} \\
& t=\frac{1,589}{\sqrt{\frac{44,02}{342}}} \\
& t=\frac{1,589}{\sqrt{0,129}} \\
& t=\frac{1,589}{0,36} \\
& t=4,41
\end{aligned}
$$

c) $\mathrm{t}$ 点数のバリュー解棌する。

自由度 $(\mathrm{df} / \mathrm{db})$ の有意義

$\mathrm{df} / \mathrm{db}=\mathrm{N}-1$

$$
\begin{aligned}
& =19-1 \\
& =18
\end{aligned}
$$

総計的に計算の結果により、 $\mathrm{t}$ 数点は $4,41>5 \%$ の有意義の $\mathrm{t}$ 表には 2,01 で、 $\mathrm{t}$ 数 点 $>1 \%$ の有意義の $\mathrm{t}$ 表には 2,88 である。というわけで、 $\mathrm{H}_{1}$ の解釈は受け取れる。そ れで、「聴解が弱い、あなたへ」という媒体での聴解の授業の結果は有意差がある。 
Ramadhan, Sutjiati, Renariah, Pemanfaatan Buku 'Choukai ga Yowai Anata e'

d) アンケットのデータで研究実験の反応

事後テストが行われた後にアンケットを配った。反応は 20 名中の 14 名がこの媒 体の使用は面白いと思われる。媒体にあるのオーディオ付けの質が良くてはっきり聴 ける。そして媒体の教材が簡単に学習することができ、言葉の種類も多様にあってア ンケットの中で対象は媒体がす寸めになると解答される。研究の状態については対象 は良い状態に研究が行われると解答される。

4. おわりに

この本研究実験によると入手された結論を次に説明する：

a. 事前テストの結果と事後テストの結果を比べると有意義がある結果は見られている。 事前テストの平均点数は 5,5 。それなら、事後テストの平均点数は 7,2 。

b. 総計的に計算の結果により、 $\mathrm{t}$ 数点は 4,41>5\%の有意義の $\mathrm{t}$ 表には 2,01 で、 $\mathrm{t}$ 数点 $>$ $1 \%$ 有意義の $\mathrm{t}$ 表には 2,88 である。というわけで、 $\mathrm{H}_{1}$ の解釈は受け取れる。

c. 20 名中の 14 名がこの媒体の使用が面白いと思われる。媒体にあるのオーディオ付け の質が良くてはっきり聴ける。そして媒体の教材が簡単に学習することができ、言葉 の種類も多様にあってアンケットの中で対象は媒体がす寸めになると解答される。研 究の状態については対象は良い状態に研究が行われると解答される。

最後には次の研究で下記のようなことを求めてほしく、説明する。

a. 聴解の研究に関する学術雑誌(ジャーナル)にある方法で実験が展開できるという期待 される。それで、指導と新しい方法として授業で使用することができる。

b. 研究実験では多様な媒体が学力を高めるために使用した。しかし、媒体を使用し中に は新しい問題が出ているか難易があるかという質問なので、次には評価でき、説明す る必要である。

\section{5. 参考文献}

Arikunto, Suharsimi. (1990) Manajemen Penelitian. Jakarta : Rineka Cipta

Brooks, Nelson. (1964) Language and Language Learning. New York : Harcourt, Brace, and World

Nurjamal, Daeng; Sumirat, Warta; Darwis Riadi. (2011) Terampil Berbahasa:Menyusun Karya Tulis Akademik, Memandu Acara (MCModerator), dan Menulis Surat. Bandung : Alfabeta

Sadiman, Arief S., dkk. (2009) Media Pendidikan : Pengertian, Pengembangan, dan Pemanfaatannya. Jakarta : Bhineka Cipta. 
JAPANEDU, Vol. 1, No. 1, April 2016

Sutedi, Dedi. (2009) Penelitian Pendidikan Bahasa Jepang. Bandung : Humaniora Press

Tarigan, Henry Guntur. (1983) Menyimak: Sebagai Suatu Keterampilan Berbahasa. Bandung : Angkasa

安藤栄里子、惠谷容子、飯嶋美知子 (2010) 耳から覚える日本語能力試験文 法トレーニング N3. Tokyo : ALC Press Inc. 